\title{
Analisis Faktor Ketaatan Beragama dan Pengaruh Teman Sebaya Terhadap Kejadian Seks Pranikah di Kabupaten Sarolangun
}

\author{
Eka Asvista Salviana, I Made Sudana, Widya Hary Cahyati \\ Program Studi S2 Kesehatan Masyarakat, Fakultas Ilmu Kesehatan \\ Universitas Negeri Semarang
}

\begin{abstract}
Abstrak
Latar belakang: Kasus seksual pranikah pada remaja dapat ditimbulkan karena berbagai macam kondisi dan tentunya juga sangat dipengaruhi oleh beberapa faktor. Tahun 2017 Badan Kependudukan dan Keluarga Berencana Nasional (BKKBN) Provinsi Jambi menemukan kasus remaja dengan rentang usia 15-19 sudah pernah melahirkan atau sedang hamil anak pertama dengan persentase 10,9\%. Penelitian ini bertujuan untuk menganalisis pengaruh ketaatan beragama dan teman sebaya melalui kontrol diri pada remaja di SMA/Sederajat Kabupaten Sarolangun Provinsi Jambi.

Metode: Studi cross sectional dilakukan di Kabupaten Sarolangun, Jambi pada tahun 2019. Jumlah sampel dalam penelitian ini adalah 371 remaja SMA dan SMK yang dipilih secara stratified random sampling. Analisis penelitian ini menggunakan path analysis.

Hasil: Hasil penelitian menunjukkan bahwa ketaatan beragama berpengaruh negatif, sedangkan faktor teman sebaya memiliki pengaruh positif dan signifikan secara langsung terhadap kejadian seks pranikah.

Kesimpulan: Terdapat pengaruh signifikan secara langsung antara ketaatan beragam dan pengaruh teman sebaya terhadap kejadian seks pranikah di Kabupaten Sarolangun.
\end{abstract}

Kata Kunci: Ketaatan Beragama, Kontrol Diri, Pengaruh Teman Sebaya, Seks Pranikah,

\section{Analysis of Religious Observance Factors and Peer Influence on Premarital Sex Events in Sarolangun}

\begin{abstract}
Background: Premarital sexual cases in adolescents can be caused due to various conditions and also strongly influenced by several factors. In 2017, the Jambi Province of National Family Planning Coordinating Board reported about 10.9\% of adolescents aged 15-19 had given birth or were pregnant with their first child. This study aimed to analyze the effect of religious obedience and peer pressure through self-control in adolescents in Senior High School and vocational high school, Sarolangun Regency, Jambi Province.

Method: The cross sectional study was conducted in Sarolangun Regency, Jambi in 2019. The number of samples in this study were 371 high school and vocational high school adolescents who were selected by stratified random sampling. Path analysis was used to analysing data.

Results: The results showed that religious obedience has a negative effect, while peer factors have a positive and significant influence directly on premarital sex events.

Conclusion: There were significants direct effect between religious and peer influence on premarital sex events in Sarolangun District.
\end{abstract}

Keywords: Premarital sexual, religious, peers effect, self-control

Alamat korespondensi:

Eka Asvista Salviana

Fakultas Ilmu Kesehatan, Universitas Negeri

Semarang, Jl. Kelud Utara III, Semarang

Email: ekaasvistasalviana@gmail.com 


\section{PENDAHULUAN}

Di Indonesia kebanyakan remaja saat berpacaran sudah pernah melakukan aktivitas berciuman sebanyak 30\% wanita dan 50\% pria. Selain itu, $5 \%$ wanita dan $22 \%$ pria sudah pernah saling meraba/diraba. Sebanyak $59 \%$ wanita dan $74 \%$ pria mengatakan sudah pernah melakukan hubungan seksual di usia 15-19 tahun. ${ }^{1}$ Pada tahun 2012 persentase remaja pria yang sudah pernah melakukan seksual sebelum menikah sebesar $4,5 \%$ dan untuk perempuan sebesar $0,7 \%$. $^{2}$ Tahun 2017 persentase remaja pria yang telah melakukan seks di luar nikah sebesar 8,0\% dan perempuan sebesar 2,0\%. Data dari BKKBN tahun 2017 menunjukkan bahwa di Provinsi Jambi terdapat kasus remaja yang pernah melahirkan atau pernah mengalami kehamilan dengan persentase $10,9 \% .^{3}$

Sejalan dengan hal di atas, berdasarkan wawancara di beberapa SMA dan SMK terhadap 10 remaja di Kabupaten Sarolangun Provinsi Jambi, terdapat 10 orang remaja pernah berpacaran, 9 orang remaja pernah berciuman, dan 10 orang remaja mengatakan pernah berpelukan.

Kasus seksual pranikah dapat ditimbulkan karena berbagai macam kondisi dan tentunya sangat dipengaruhi oleh faktor ketaatan beragama dan pengaruh dari teman sebaya. ${ }^{4}$ Informasi di atas menggambarkan adanya pergeseran nilai- nilai tindakan seksual pranikah yang dilakukan remaja, karena itu penulis tertarik melakukan penelitian Analisis Faktor Ketaatan Beragama dan Pengaruh Teman Sebaya terhadap Kejadian Seks Pranikah di Kabupaten Sarolangun.

\section{METODE}

Penelitian ini menggunakan pendekatan cross-sectional. Populasi dalam penelitian ini adalah siswa SMA dan SMK di Kabupaten Sarolangun, Jambi pada tahun 2019 dengan jumlah keseluruhan 5.028 orang. Sampel pada penelitian ini menggunakan stratified random sampling, sampel yang didapatkan sebesar 371 remaja.

Sebelum mengumpulkan data, peneliti mengurus Ethical Clearance di Universitas Negeri Semarang dengan Nomor 025/KEPK/EC/2020. Pengumpulan data dengan menggunakan instrumen kuesioner dengan pertanyaan tertutup. Kuesioner dalam penelitian ini adalah angket seks pranikah sebagai variabel terikat, kontrol diri sebagai variabel intervening, dan ketaatan beragama serta pengaruh teman sebaya sebagai varibel bebas. Analisis pada penelitian kuantitatif meliputi analisis data awal dan analisis data akhir. Analisis data awal meliputi uji normalitas. Setelah hasil pada uji normalitas disimpulkan semua data berdistribusi normal kemudian peneliti menganalisis data akhir dengan menggunakan path analysis yang merupakan pengembangan dari regresi berganda.

\section{HASIL}

\section{Analisis Univariat}

Berdasarkan hasil analisis univariat pada variabel jenis kelamin menunjukkan bahwa responden perempuan lebih banyak terlibat dalam penelitian ini, yaitu dengan jumlah 212 atau $(57,1 \%)$. Sementara untuk laki-laki berjumlah 159 responden atau $(42,9 \%)$. Pada variabel usia menunjukkan bahwa remaja dalam penelitian ini berada pada rentang usia 17 tahun yaitu berjumlah 100 remaja atau $(27,0 \%)$ sedangkan paling sedikit ditemukan pada usia 20 tahun yaitu berjumlah 1 responden atau $(0,3 \%)$. Pendidikan terakhir ayah responden adalah SMP yaitu berjumlah 151 responden atau $(40,7 \%)$ sedangkan paling sedikit ditemukan pada pendidikan sarjana yaitu berjumlah 7 responden atau (1,9\%). Pendidikan terakhir ibu responden adalah SMP yaitu berjumlah 149 responden atau $(40,2 \%)$ sedangkan paling sedikit ditemukan pada pendidikan sarjana yaitu berjumlah 11 responden atau $(3,0 \%)$.

Tabel 1. Distribusi Frekuensi Karakteristik Responden berdasarkan Jenis Kelamin, Usia, Pendidikan Ayah dan Pendidikan Ibu

\begin{tabular}{|c|c|c|c|}
\hline \multirow{3}{*}{$\begin{array}{l}\text { Jenis } \\
\text { Kelamin }\end{array}$} & & Jumlah & $\begin{array}{l}\text { Persentase } \\
(\%)\end{array}$ \\
\hline & Perempuan & 212 & 57,1 \\
\hline & Laki-laki & $\underline{159}$ & $\underline{42,1}$ \\
\hline \multirow[t]{6}{*}{ Usia } & 15 tahun & 80 & 21,6 \\
\hline & 16 tahun & 90 & 24,3 \\
\hline & 17 tahun & 106 & 28,6 \\
\hline & 18 tahun & 74 & 19,9 \\
\hline & 19 tahun & 20 & 5,4 \\
\hline & 20 tahun & 1 & 0,3 \\
\hline
\end{tabular}




\begin{tabular}{llrr}
\hline Pendidikan & SD & 89 & 24,0 \\
Ayah & SMP & 151 & 40,7 \\
& SMA & 115 & 31,0 \\
& SMK & 9 & 2,4 \\
& Sarjana & 7 & 1,9 \\
\hline Pendidikan & SD & 124 & 33,4 \\
Ibu & SMP & 149 & 40,2 \\
& SMA & 87 & 23,5 \\
& Sarjana & 11 & 3,0 \\
\hline
\end{tabular}

Diketahui bahwa dari 371 responden sebanyak 184 responden atau $(39,6 \%)$ mempunyai ketaatan beragama yang tinggi sedangkan responden dengan ketaatan beragama yang rendah sebanyak 103 responden atau $(22,1 \%)$, dengan demikian dapat dinyatakan bahwa ketaatan beragama remaja dalam kategori tinggi. Sebanyak 270 responden atau $(58,1 \%)$ memiliki pengaruh teman sebaya yang tinggi sedangkan responden dengan pengaruh teman sebaya yang rendah sebanyak 56 responden atau $(12,0 \%)$, dengan demikian dapat dinyatakan bahwa pengaruh teman sebaya yang dimiliki remaja dalam kategori tinggi. Terdapat 187 responden atau $(40,2 \%)$ masih memiliki kontrol yang rendah terhadap dirinya sendiri, sedangkan remaja dengan kontrol yang tinggi sebanyak 104 responden atau $(22,4 \%)$, dengan demikian dapat dinyatakan bahwa kontrol yang dimiliki remaja dalam kategori rendah.

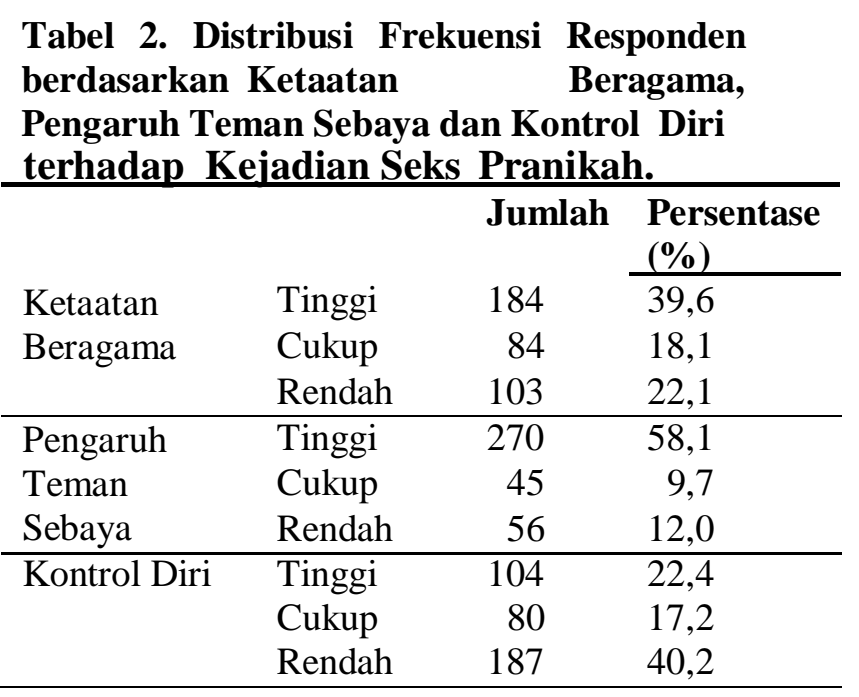

\section{Analisis Jalur}

Penelitian ini dilaksanakan di SMA dan SMK Kabupaten Sarolangun Provinsi jambi, hasil penelitian berupa analisis faktor seks pranikah melalui kontrol diri pada remaja meliputi ketaatan beragama dan pengaruh teman sebaya.
Tabel 3. Hasil pengaruh terhadap variabel mediasi kontrol diri

\begin{tabular}{|c|c|c|c|}
\hline Variabel & $\begin{array}{l}\text { Koefisien } \\
\text { Regresi } \\
\text { (B) }\end{array}$ & $\mathrm{t}_{\text {hitung }}$ & Sig t \\
\hline $\begin{array}{l}\text { Ketaatan } \\
\text { Beragama }\end{array}$ & $-0,160$ & $-3,161$ & 0,002 \\
\hline $\begin{array}{l}\text { Pengaruh } \\
\text { Teman Sebaya }\end{array}$ & 0,122 & 2,223 & 0,027 \\
\hline
\end{tabular}

Berdasarkan tabel di atas hasil analisis uji pengaruh ketaatan beragama (X1) dan pengaruh teman sebaya (X2) terhadap kontrol diri (Y1). Hasil analisis jalur variabel ketaatan beragama menunjukkan nilai statistik untuk kontrol diri sebagai variabel intervenin antara ketaatan beragama dan kejadian seks pranikah sebesar -3,161 dengan p-value (sig.) bernilai $0,002(\mathrm{p}<0,05)$. Sedangkan hasil analisis jalur variabel teman sebaya menunjukkan nilai statistik untuk kontrol diri sebagai variabel intervenin antara teman sebaya dan kejadian seks pranikah sebesar 2,223 dengan $p$-value (sig.) bernilai 0,027 ( $<$ 0,05).

Tabel 4. Hasil dari penelitian pengaruh langsung terhadap kejadian seks pranikah

\begin{tabular}{|c|c|c|c|}
\hline Variabel & $\begin{array}{l}\text { Koefisien } \\
\text { Regresi } \\
\text { (B) }\end{array}$ & $\mathrm{t}_{\text {hitung }}$ & Sig t \\
\hline $\begin{array}{l}\text { Ketaatan } \\
\text { Beragama }\end{array}$ & $-0,101$ & $-2,288$ & 0,023 \\
\hline $\begin{array}{l}\text { Pengaruh } \\
\text { Teman } \\
\text { Sebaya }\end{array}$ & 0,097 & 2,037 & 0,042 \\
\hline Kontrol Diri & $\underline{0,099}$ & 2,191 & $\underline{0,029}$ \\
\hline
\end{tabular}

Berdasarkan tabel di atas hasil analisis jalur menunjukkan bahwa untuk variabel ketaatan beragama menunjukkan nilai t sebesar -2,288 dengan analisis jalur 0,101 dengan nilai signifikan hitung 0,023. Sedangkan hasil dari variabel teman sebaya menunjukkan bahwa nilai $\mathrm{t}$ 2,037 dengan analisis jalur 0,097 dan nilai hitung 0,042. Berdasarkan hasil analisis jalur kontrol diri menunjukkan bahwa nilai $t$ 2,191 dengan analisis jalur 0,099 dan nilai signifikansi hitung 0,029 .

\section{PEMBAHASAN}

Berdasarkan tabel 3, hasil analisis jalur variabel ketaatan beragama menunjukkan nilai ( $t$-value) untuk kontrol 
diri sebagai variabel intervening antara ketaatan beragama dan kejadian seks pranikah sebesar -3,161 dengan p-value (sig.) bernilai 0,002 oleh karena itu maka dapat disimpulkan bahwa pengaruh tidak langsung signifikan dengan hubungan yang negatif, artinya apabila ketaatan beragama meningkat maka akan meningkatkan konrol diri remaja untuk tidak melakukan seks pranikah. Oleh karena itu, hipotesis tentang ketataan beragama berpengaruh terhadap kejadian seks pranikah melalui kontrol diri diterima, artinya ketaatan beragama yang tinggi dan kontrol diri yang tinggi menjadikan kejadian seks pranikah menjadi rendah begitupun sebaliknya.

Sejalan dengan penelitian di atas, siswa yang memiliki ketaatan beragama rendah berisiko 58 kali lebih besar untuk hamil dibandingkan remaja dengan ketataan beragama tinggi. ${ }^{5}$ Penelitian pada mahasiswa di Banten di dapatkan bahwa remaja yang taat melaksanakan ibadah agama menjadikan mereka dapat mengendalikan seks pranikah. Remaja yang taat dalam beribadah dapat mengontrol diri dan mampu menjaga saat berhadapan dengan lawan jenis. ${ }^{6}$

Hasil analisis jalur pengaruh teman sebaya menunjukkan nilai statistik untuk kontrol diri sebagai variabel intervening antara pengaruh teman sebaya dan kejadian seks pranikah sebesar 2,223 dengan (sig.) bernilai 0,027, oleh karena itu disimpulkan bahwa pengaruh tidak langsung signifikan dengan hubungan yang positif, artinya apabila pengaruh teman sebaya meningkat dan kurangnya kontrol diri remaja maka akan meningkatkan remaja untuk melakukan seks pranikah. Oleh karena itu, hipotesis tentang -teman sebaya berpengaruh terhadap kejadian seks pranikah melalui kontrol diri diterima, artinya pengaruh teman sebaya yang tinggi dan kurangnya kontrol pada remaja menjadikan kejadian seks pranikah menjadi tinggi begitu juga sebaliknya.

Teman sebaya dengan kategori buruk sebanyak 58,7\%, sedangkan yang memiliki teman sebaya dengan pengaruh baik sebanyak $41,3 \% .^{7} \mathrm{Hal}$ di atas terjadi karena adanya dorongan yang berasal dari luar atau lingkungan yaitu melihat temannya berpacaran dan melakukan seksual pranikah, sehingga memicu keinginan remaja untuk mengikuti hal yang sama. ${ }^{8}$ Penelitian yang dilakukan di sekolah menengah atas di negara bagian Kaduna, Nigeria menunjukkan bahwa, tekanan teman sebaya sebagai salah satu faktor utama yang mempengaruhi remaja. ${ }^{9}$

Berdasarkan tabel 4, hasil analisis jalur menunjukkan bahwa untuk variabel ketaatan beragama menunjukkan nilai $t$ sebesar -2,288 dengan analisis jalur 0,101 dan nilai signifikansi hitung 0,023 Setiap kenaikan ketaatan beragama satu satuan maka kejadian seks pranikah mengalami penurunan 0,101 , hasil tersebut menunjukkan arah hubungan negatif, dengan demikian semakin tinggi ketaatan beragama maka semakin rendah kejadian seks pranikah. Oleh karena itu, hipotesis tentang ketaatan beragama berpengaruh terhadap kejadian seks pranikahll diterima, artinya tingkat agama yang rendah menjadikan kejadian seks pranikah menjadi tinggi begitupun sebaliknya.

Tingginya sikap remaja terhadap religiusitas maka semakin rendah kemungkinan remaja untuk melakukan perilaku seks pranikah dan berlaku juga

sebaliknya. Tingkat religiusitas sesorang sangat efektif sebagai cara untuk mencegah diri kita pada kecenderungan untuk melakukan seks pranikah. ${ }^{10}$

Hasil analisis jalur pengaruh teman sebaya menunjukkan nilai signifikansi sebesar 2,037 dengan analisis jalur 0,097 dan nilai signifikansi hitung 0,042. Setiap kenaikan pengaruh teman sebaya satu satuan maka kejadian seks pranikah mengalami penurunan 0,097. Oleh karena itu, hasil tersebut menunjukkan arah hubungan yang positif, demikian semakin tinggi pengaruh teman sebaya maka akan meningkatkan kejadian seks pranikah. Oleh karena itu, hipotesis tentang teman sebaya berpengaruh terhadap kejadian seks pranikah diterima, artinya pengaruh teman sebaya yang tinggi menjadikan kejadian seks pranikah menjadi tinggi begitupun sebaliknya.

Remaja yang memiliki teman sebaya dengan pengaruh buruk cenderung akan berperilaku seksual berisiko sebanyak 1,73 
kali. ${ }^{11}$ Sumber informasi yang paling banyak didapatkan adalah dari teman sebaya pada saat berkumpul ataupun bersama, remaja mengungkapkan bahwa banyak teman mereka yang melakukan seksual melebihi batas dan ratarata itu semua dilakukan karena cinta. ${ }^{12}$

Berdasarkan hasil analisis jalur kontrol diri menunjukkan bahwa nilai signifikan sebesar 2,191 dengan analisis jalur 0,099 dan nilai signifikansi hitung 0,029. Hal ini berarti bahwa setiap kenaikan kontrol diri satu satuan makakejadian seks pranikah mengalami penurunan 0,105 . Oleh karena itu, hasil tersebut menunjukkan arah hubungan positif antara kontrol diri dengan kejadian seks pranikah. Oleh karena itu, hipotesis ke tujuh tentang kontrol diri berpengaruh terhadap kejadian seks pranikah diterima. Artinya, kontrol diri yang rendah menjadikan kejadian seks pranikah menjadi tinggi begitupun sebaliknya.

Hasil penelitian menunjukan bahwa kontrol diri berpengaruh terhadap kejadian seks pranikah, hal itu karena siswa yang mempunyai kontrol terhadap dirinya dapat berpikir untuk tidak merusak masa remajanya dan siswa juga mempunyai keinginan untuk melanjutkan ke sekolah yang lebih tinggi, hal tersebut membuat kontrol diri siswa dalam melakukan kesalahan khususnya seks pranikah menjadi berkurang. Hal ini sejalan dengan penelitian di MAN Samarinda 1 mangatakan bahwa tingginya kontrol diri yang dimiliki seseorang maka akan menurunkan kejadian seks pranikah dan begitu juga sebaliknya. ${ }^{13}$

\section{SIMPULAN}

Berdasarkan hasil penelitian dan pembahasan mengenai Analisis Faktor Ketaatan Beragama dan Pengaruh Teman Sebaya terhadap Kejadian Seks Pranikah di Kabupaten Sarolangun menyimpulkan bahwa ketaatan beragama berpengaruh negatif dan signifikan terhadap seks pranikah, selanjutnya teman sebaya mempengaruhi secara positif dan signifikan terhadap kejadian seks pranikah.

\section{DAFTAR PUSTAKA}

1. BKKBN, BPS, Kemenkes, USAID. Survei Demografi dan Kesehatan Indonesia 2017. SDKI 2017. Jakarta; 2018.

2. BKKBN, BPS KK. Survei Demografi dan
Kesehatan Indonesia (SDKI) 2012. Jakarta; 2012.

3. BKKBN, BPS, Kemenkes. Survei Demografi Dan Kesehatan Indonesia 2017 [Internet]. 2017. p. 1-606. Available from:

http://www.google.com/url?sa=t\&rct=j\&q $=\&$ esrc $=$ s\&source $=$ web $\& c d=1 \& c a d=r j a \&$ uact $=8 \&$ ved $=2$ ahUKEwjC0MCG0tDmAh WXSH0KHdtlC_kQFjAAegQIARAC\&ur l=http://sdki.bkkbn.go.id/files/buku/2017I DHS.pdf\&usg=AOvVaw3xYxUlCwBbs7 EAR9O-dqJ9

4. R C, DK S. Faktor-faktor yang Berhubungan dengan Perilaku Seksual Remaja di Desa Mega Mendung Kecamatan Mega Mendung Kabupaten Bogor Provinsi Jawa Barat Tahun 2016. J Ilmu dan Budaya Ed Khusus Fak Ilmu Kesehat. 2017;40(57):6587-97.

5. Notobroto HBE M. Pengaruh Aktivitas Seksual Pranikah, Ketaatan Beragama dan Sosial Ekonomi terhadap Kehamilan Remaja di Kecamatan Saptosari Gunungkidul. J Biometrika dan Kependud. 2017;5(1):19-26.

6. SEN S. Faktor-Faktor Yang Mempengaruhi Perilaku Seks Pranikah Pada Mahasiswa Akademi Kesehatan X Di Kabupaten Lebak. J Kesehat. 2013;2(1):50-5.

7. F A, K A, CA F, D K, K P. Faktor-Faktor Yang Berhubungan Dengan Perilaku Seksual Pranikah Beresiko Kehamilan Tidak Diinginkan (KTD) Pada Mahasiswa. J Dunia Kesmas. 2014;3(4):257-62.

8. M R, Y Z. Kematangan Beragama Remaja Akhir Sebagai Pelaku Seksual Pranikah. J Indegenous. 2017;2(1):49-59.

9. Badaki OL, Adeola MF. Influence of Peer Pressure as a Determinant of Premarital Sexual Behaviour among Senior Secondary School Students in Kaduna State, Nigeria. J Multidiscip Res Healthc. 2017;3(2):151-9.

10. VT N, IW W. Hubungan antara Sikap terhadap Religiusitas dengan Sikap terhadap Kecenderungan Perilaku Seks Pranikah pada Remaja akhir yang sedang Berpacaran di Universitas Airlangga Surabaya. J Psikol Kepribadian dan Sos. 2014;3(2):21-7.

11. AK D. Hubungan Kontrol Diri Dengan Perilaku Seksual Pranikah Pada Mahasiswa Universitas Negeri Semarang. 
J Psychol Univ Negeri Semarang. 2014;1(1):21-7.

12. N F, A S, RN A, P P. Perilaku Seksual Remaja Putri di SMK I Nusantara Ciputat Tahun 2012. J Kesehat Reproduksi2. 2012;3(3):151-60.
13. A K. Hubungan Religiusitas dan Kontrol Diri dengan Perilaku Seksual Pranikah Remaja di MAN 1 Samarinda. eJournal Psikol. 2013;1(2):220-9. 